\title{
Ecophysiological characterization of early successional biological soil crusts in heavily human-impacted areas
}

\author{
Michelle Szyja $^{1}$, Burkhard Büdel ${ }^{1}$, and Claudia Colesie ${ }^{2}$ \\ ${ }^{1}$ Department of Plant Ecology and Systematics, University of Kaiserslautern, Kaiserslautern, Germany \\ ${ }^{2}$ Department of Forest Genetics and Plant Physiology, Swedish University of Agricultural Sciences (SLU), Umeå, Sweden
}

Correspondence: Michelle Szyja (michelle.szyja@web.de)

Received: 29 August 2017 - Discussion started: 18 September 2017

Revised: 13 February 2018 - Accepted: 15 February 2018 - Published: 3 April 2018

\begin{abstract}
Ecophysiological characterizations of photoautotrophic communities are not only necessary to identify the response of carbon fixation related to different climatic factors, but also to evaluate risks connected to changing environments. In biological soil crusts (BSCs), the description of ecophysiological features is difficult, due to the high variability in taxonomic composition and variable methodologies applied. Especially for BSCs in early successional stages, the available datasets are rare or focused on individual constituents, although these crusts may represent the only photoautotrophic component in many heavily disturbed ruderal areas, such as parking lots or building areas with increasing surface area worldwide. We analyzed the response of photosynthesis and respiration to changing BSC water contents (WCs), temperature and light in two early successional BSCs. We investigated whether the response of these parameters was different between intact BSC and the isolated dominating components. BSCs dominated by the cyanobacterium Nostoc commune and dominated by the green alga Zygogonium ericetorum were examined. A major divergence between the two BSCs was their absolute carbon fixation rate on a chlorophyll basis, which was significantly higher for the cyanobacterial crust. Nevertheless, independent of species composition, both crust types and their isolated organisms had convergent features such as high light acclimatization and a minor and very late-occurring depression in carbon uptake at water suprasaturation. This particular setup of ecophysiological features may enable these communities to cope with a high variety of climatic stresses and may therefore be a reason for their success in heavily disturbed areas with ongoing human impact. However, the shape of the response was different for intact BSC compared to separated organ-
\end{abstract}

isms, especially in absolute net photosynthesis (NP) rates. This emphasizes the importance of measuring intact BSCs under natural conditions for collecting reliable data for meaningful analysis of BSC ecosystem services.

\section{Introduction}

In drylands, the ecophysiological characterization of biological soil crusts (BSCs) is a useful instrument for the evaluation and prediction of ecosystem functioning under recent climate change scenarios (Maestre et al., 2011). Biological soil crusts are small-scale communities, composed of bryophytes, lichens, cyanobacteria, green algae, heterotrophic bacteria and microfungi, within or on top of the uppermost millimeters of soil surfaces (Belnap et al., 2016), that are often used as model systems to characterize the biodiversity-ecosystem-function relationship in soils (Bowker et al., 2010). While there is sound documentation regarding ecophysiological characterizations for BSC organisms from hot and cold deserts as well as drylands (Hawes et al., 1992; Lange et al., 1992; Housman, 2006; Novis et al., 2007), studies from temperature regions are rare. In temperate regions, BSCs are not a typical "steady state" vegetation type. They are either restricted to continuously disturbed habitats, are an initial stage of succession after heavy disturbances or present in areas held in arrested succession. In such early successional stages, BSCs are mainly composed of cyanobacteria and/or green algae (Fischer et al., 2010). Although the physiological capacity of these organisms may be negligible in relation to lichen- and bryophyte-dominated 
BSCs (Belnap et al., 2001), they are crucial study organisms for understanding BSC function in temperate regions.

In temperate regions anthropogenic disturbances such as forestry, traffic lanes or trampling create new land surfaces (Walker and Willig, 1999) where microclimatic conditions can favor BSC development (Webb et al., 1983). This is due to the fact that BSCs in general are initial colonizers of open surfaces (Fischer et al., 2010; Veste et al., 2011) where cyanobacteria and green algae appear as pioneers (Belnap, 2006). Ongoing disturbance prevents proceeding recovery; thus, the species richness remains at a low level, a phenomenon also referred to as arrested succession (Webb and Wilshire, 2012). In the natural BSC succession, lichens and bryophytes would broaden the initial colonization (Belnap and Eldrigde, 2001; Belnap, 2006); however, in areas of arrested succession cyanobacteria and green algae are more resistant to the disturbance and thus remain the dominant BSC organisms (Kuske et al., 2012). Areas where vegetation remains in a state of arrested succession are appearing more frequently due to a growing need for space by humans (Housman, 2006), and new habitats derived from accelerating human activities are fairly understudied (Rindi, 2007). Aside from ongoing human disturbance, areas affected negatively by climate change might experience shifts in species composition towards cyanobacteria and green algae as the dominant BSC contributors, due to warming and a lower water availability (Escolar et al., 2012; Reed et al., 2012; Zelikova et al., 2012). These areas will increase in space until the end of the 21st century (Solomon et al., 2007), which strengthens the need for ecophysiological investigations on cyanobacteria and green algae in the BSC context. Nonetheless, climax communities with mosses or lichens being present exist also in dry areas with high temperatures (e.g., Zedda et al., 2011 or Weber et al., 2012), so it is not possible to generalize this pattern.

Organisms of ruderal habitats often possess specific physiological adaptations, for example, high physiological plasticity (Grime and Pierce, 2012). Cyanobacteria and green algae are key constituents and only the primary producers during (a) early succession; (b) regeneration processes of habitats under constant anthropogenic pressure; and (c) in BSCs of demanding habitats, for example, hot (Büdel, 1999) and cold deserts (Karsten et al., 2010; Büdel et al., 2016). Typical taxa of green algae and cyanobacteria found in early successional BSCs of the temperate zone are, for example, Zygogonium ericetorum (Pluis, 1994; Büdel, 2001a), Klebsormidium spp. (Pluis, 1994), Microcoleus spp. (Belnap et al., 2001) and Nostoc spp. (Pandey et al., 2005).

Comparing ecophysiological literature of cyanobacteria and green algae reveals that cyanobacteria are in general a well-studied group of organisms. In the absence of other photoautotrophic organisms in BSCs, they provide the most important ecosystem services (Makhalanyane et al., 2015, and sources therein). Terrestrial cyanobacteria are important in many ecosystems, due to their ability to fix atmospheric ni- trogen and sequester carbon (Dojani et al., 2011; Büdel et al., 2016) and play important roles in global biogeochemical cycles (Raven, 2012). Most studies on the ecophysiology of single cyanobacteria species or cyanobacteria-dominated BSCs were carried out in desert or polar environments (Hawes et al., 1991; Lange et al., 1992; Housman, 2006; Novis et al., 2007). In contrast to cyanobacteria, reliable records of eukaryotic algal groups appear to be restricted to studies in soils of temperate and alpine regions (Karsten and Rindi, 2010). Although green-algae-dominated BSCs occur rarely in temperate regions, where they do, they have high soil surface coverage (Büdel et al., 2016). Green algae serve as key organisms in BSC formation in all ecosystems, especially in temperate, arctic and high alpine regions (Büdel et al., 2016). A lack of information on green algae in general and especially on temperate, ruderal areas seems surprising because green algae occur in virtually all terrestrial habitats and on manmade surfaces (Gaylarde and Morton, 1999; Tomaselli et al., 2000; Büdel, 2011). The ecosystem services provided by green algae include stabilization of soil surfaces, improvement of soil structure, soil fertility and the influencing of hydrological processes (Bailey et al., 1973; Hu et al., 2002; Reisser, 2007). The current status of ecophysiology of terrestrial green algae has been described as being based on assumptions and deductions rather than on experimental data (Reisser, 2007). Additionally, most green algae-focused studies have investigated organisms after a prolonged period of cultivation (e.g., Karsten and Rindi 2010; Karsten et al., 2010), which could have changed their ecophysiological responses over time, as these organisms are well known to have a high acclimatization potential to differing environmental factors (Colesie et al., 2014; Belnap et al., 2016).

One application for detailed ecophysiological descriptions is modeling on a global scale. Post millennial interest in carbon gain of BSCs has increased (Lange and Belnap, 2016) and their $\mathrm{CO}_{2}$ exchange rates are now considered relevant even on a global scale (Elbert et al., 2012; Porada et al., 2013, 2014). Unfortunately, modern process-based models as used by Porada et al. $(2013,2014)$ are still based on few available datasets that cover few different BSC types, organisms, geographical regions, and climatic situations which even exclude cyanobacteria and green-algae-dominated BSCs. Problematic is also the focus on isolated organisms rather than studying the whole BSC system (see Colesie et al., 2016, or sources in Elbert et al., 2012). One organism studied out of several BSC organisms does not represent the ecological response of a complete BSC (Weber et al., 2012).

The goal of this study is to present a detailed description of the ecophysiological performance of a cyanobacterial and a green-algae-dominated BSC regarding their photosynthetic response to different water, light and temperature conditions of temperate habitats. This will allow an overview of in situ gas exchange rates correlated to local climate and therefore produce a suitable database for potential global-scale models. The study also provides an ecophysiological dataset for 
BSCs in habitats with ongoing human disturbance. Additionally, it demonstrates the value of measuring BSCs as a system instead of as single components.

Two major research questions were raised:

1. What is the ecophysiological performance of an intact cyanobacterial or green algal BSC? A higher physiological flexibility is predicted for cyanobacteria and green algae compared to bryophytes and lichens. This would enable the groups to cope with a wide range of abiotic stresses.

2. To what extent can the photosynthetic rate of the BSC be delineated from single organism measurements? We expect differences between measurements of complete BSCs (with attached soil and soil organisms), of the isolated organisms and of bare soil alone. In theory, a mathematical addition of "separated organisms" plus "bare soil" should equal the complete system reading.

\section{Material and methods}

\subsection{Study site and organisms}

Two anthropogenically impacted sites with constant disturbance were selected. Both sites were located in southwestern Germany (Fig. 1a) and were dominated by either green algae or cyanobacteria. The sites were $50 \mathrm{~km}$ from each other, which excludes any macroclimatic differences. Mean annual air temperature is $9.9^{\circ} \mathrm{C}$ and mean annual precipitation $741.3 \mathrm{~mm}$ (weather station of the Agrarmeteorologie Rhineland-Palatinate Morlautern).

Site 1 -Mehlinger heath. The Mehlinger heathland ( $\mathrm{MH}$, Fig. 1b) is a former military training ground (Ruby, 1979) close to the city of Kaiserslautern $\left(49^{\circ} 48^{\prime} \mathrm{N}, 7^{\circ} 83^{\prime} \mathrm{E}\right)$. Once the military use was abandoned, a BSC dominated by green algae developed between dense heather stands, which formed as a part of the natural successional process. With 150 ha, the site is the largest heathland system of southern Germany. It is situated 320 to $340 \mathrm{~m}$ a.s.l. and soils are acidic $(\mathrm{pH}=5.28$, Felde, personal communication), mostly due to their origin from red sandstone of the early Triassic (Landesamt für Geologie und Bergbau, Rhineland-Palatinate, 2016), with a loamy soil texture, very low organic carbon content $(<1 \%)$ and a water holding capacity of $40 \%$. Since 2001 it has been a natural reserve with an ongoing human management regime to preserve the heathland system. Vascular plant vegetation is dominated by Calluna vulgaris. In general, the cryptogamic diversity concerning cyanobacteria and green algae in this habitat is poor (Stanula, 2011), with only five and one species described, respectively. The sampling site is close to a lookout point, where trampling is unpreventable. The dominant organism in the occurring BSC is the green alga Zygogonium ericetorum (Fig. 1c).
Site 2 - parking lot. Cyanobacteria-dominated BSC samples were collected from a parking lot (PL) at an equestrian farm (Fig. 1d) near the city of Zweibrücken $\left(49^{\circ} 19^{\prime} \mathrm{N}\right.$, $\left.7^{\circ} 25^{\prime} \mathrm{E}\right), 369 \mathrm{ma}$ a.s.1. The bedrock is composed of base-rich ( $\mathrm{pH}=6.81$; Felde, personal communication) limestone that originates from the early Triassic with a coarse gravel overlay, with a loamy sand soil texture, $6 \%$ organic carbon and a water holding capacity of $30 \%$. Daily use by cars and trampling prevent the development of higher vegetation. Some bryophyte species occur: Hypnum cupressiforme and Tortula muralis. The cyanobacterium Nostoc commune Vaucher ex Bornet and Falhault (Fig. 1e) is the dominant organism in these BSCs and is clearly visible with the naked eye. Sampling depth at both sides was between 0.8 to $1 \mathrm{~cm}$.

\subsection{Sample collection}

Sample collection was conducted in spring 2016 at both study sites. Samples were selected according to the dominant occurrence of $N$. commune or $Z$. ericetorum. A green algal or cyanobacteria-dominated BSC was defined as covering at least $50 \%$ of the soil surface in a $20 \mathrm{~cm}$ diameter petri dish. Once collected, the samples were first allowed to dry at room temperature and then were kept frozen at $-20^{\circ} \mathrm{C}$ until measurements. Frozen storage is described as being suitable for long-term storage of BSC components for experimental studies (Tamaru et al., 2005; Seckbach, 2007).

\section{$2.3 \mathrm{CO}_{2}$ exchange}

$\mathrm{CO}_{2}$ exchange measurements were completed according to Colesie et al. (2014). Before measurements, the intact BSC samples underwent a reactivation process which consisted of 2-day exposure to $4{ }^{\circ} \mathrm{C}$ in the dark. Afterwards they were fixed in the gas exchange cuvette and sprayed with sterile, filtered water to activate their metabolism $24 \mathrm{~h}$ prior to measurement. Ahead of the measurements, full water saturation was achieved by submerging the samples in water for $10 \mathrm{~min}$. Excessive water and droplets were carefully shaken from the sample before measurements.

Within each crust type (cyanobacterial and green algal) three separate series of measurements were conducted. First the intact crust (named $\mathrm{BSC}_{\text {all }}$; defined as the entire nonmanipulated BSC including attached soil with an unknown amount of heterotrophic organisms) was used for the measurements. Once these were completed we separated the dominant organisms from the crust and measured the separated organism (named $\mathrm{BSC}_{\mathrm{dom}}$; the dominant organism of the crust, isolated from the soil, washed and dissected thoroughly) and the underlying soil (named $\mathrm{BSC}_{\text {soil }}$; the underlying soil and all other microscopic organisms, except for the dominant one) separately. The following terminology will henceforth be used for the cyanocrust: $\mathrm{C}-\mathrm{BSC}_{\mathrm{all}}, \mathrm{C}-\mathrm{BSC}_{\mathrm{dom}}$ and $\mathrm{C}-\mathrm{BSC}_{\text {soil }}$; the following will be used for the green algal crust: $\mathrm{G}_{-} \mathrm{BSC}_{\mathrm{all}}, \mathrm{G}-\mathrm{BSC}_{\mathrm{dom}}$ and $\mathrm{G}-\mathrm{BSC}_{\text {soil }}$. 


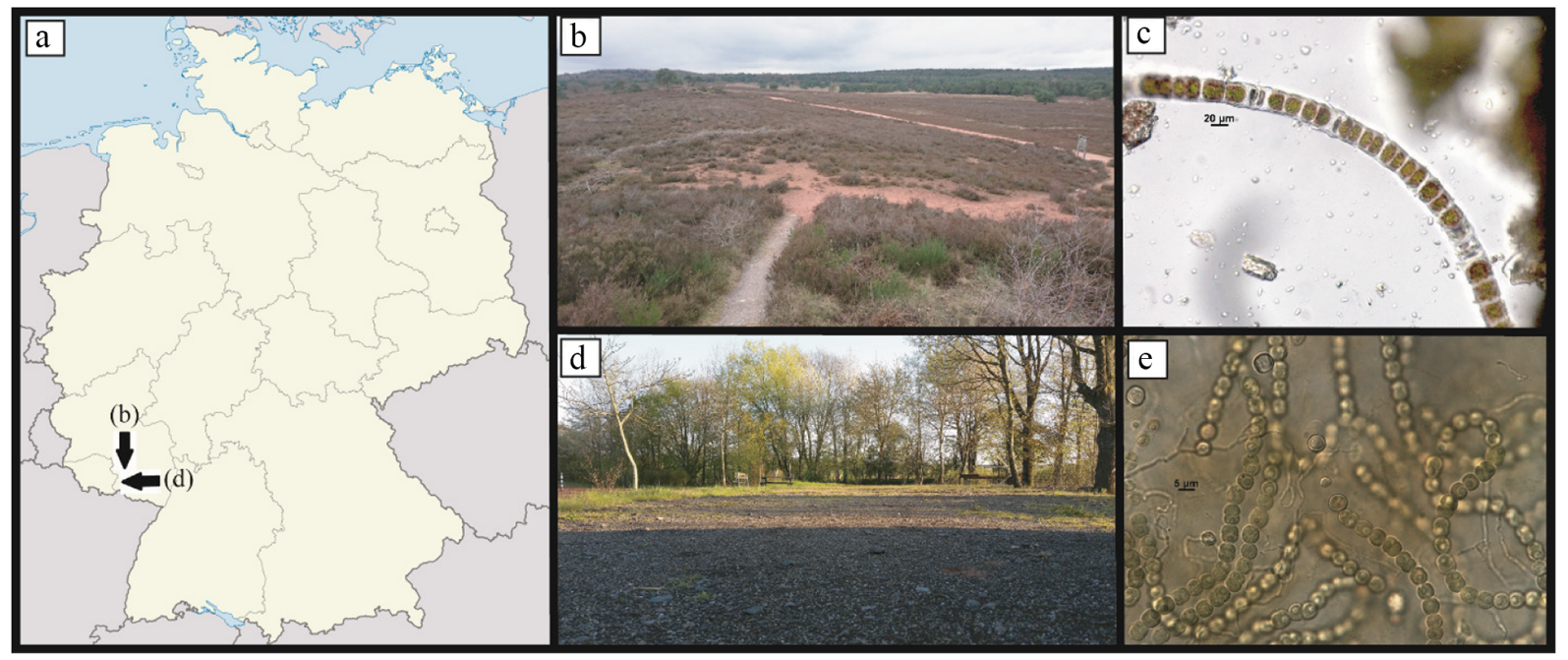

Figure 1. Organisms and map of the study site in Germany, Rhineland-Palatinate (a): top pictures are from study site 1, Mehlinger heath viewed from the lookout (b) and microscopic images of the crust-dominating organism Zygogonium ericetorum (c); bottom depicts study site 2, a parking lot at an equestrian farm near Zweibrücken (d) and microscopic images of the crust-dominating organism Nostoc commune (e).

The $\mathrm{CO}_{2}$ gas exchange measurements were conducted under controlled laboratory conditions using a minicuvette system (GFS 3000, Walz company, Effeltrich, Germany). To obtain full ecophysiological response to changing light conditions and water contents (WCs) fully hydrated samples ( $n=3$ each sampling site) were exposed to stepwise increasing light from 0 to $2000 \mu \mathrm{mol}$ photons $\mathrm{m}^{-2} \mathrm{~s}^{-1}(0,25,50$, $100,300,500,1000,1500,1750,2000$ photons $\left.\mathrm{m}^{-2} \mathrm{~s}^{-1}\right)$ at two temperatures $\left(17\right.$ and $25^{\circ} \mathrm{C}$ ) and ambient $\mathrm{CO}_{2}$ concentrations to test for light levels required to saturate the photosynthesis and the operation temperature for this experiment. The lack of difference between the light saturation points at these two temperatures (grouped $t$ test; C-BSC $\mathrm{Ball}_{\text {all }}$ : $t$ value $=-0,971, \mathrm{FG}=3, p=0.403$; G-BSC $\mathrm{Blll}_{\text {all }}: t$ value $=$ $-1,271, \mathrm{FG}=4, p=0.273$ ) demonstrated that light saturation does not vary with temperature and could therefore be held stable during the following experiments. The light cycles (about 40 min duration) were repeated until the samples were completely dry (after 6-7 h) and samples were weighted after each light cycle in order to determine the water content. WC was calculated as $\mathrm{mm}$ precipitation equivalent. Sample dry weight was determined after 3 days in a drying oven (Heraeus Instruments T6P, Thermo Fisher Scientific Inc.) at $60^{\circ} \mathrm{C}$. The $\mathrm{CO}_{2}$ exchange of the samples was related to soil crust surface and chlorophyll content, the latter determined after Ronen and Galun (1984). The curves for the $25^{\circ} \mathrm{C}$ measurements were fitted with the Smith function (e.g., Lange et al., 1998) and light saturation was defined as the photosynthetic photon flux density at $90 \%$ of maximum NP according to the fitted curve. Light compensation was the intersection of the curve with the $x$ axis, calculated from the last negative and first positive point of the fitted curve, which was completed for each sample separately.

Additionally, the response of net photosynthesis (NP) and dark respiration (DR) to water content at different temperatures was determined from complete desiccation cycles (the water saturated phase to the air-dried status) at saturating light conditions (the operational light was set to $985 \mu \mathrm{mol}$ photons $\mathrm{m}^{-2} \mathrm{~s}^{-1}$ for C-BSC and $1260 \mu \mathrm{mol}$ photons $\mathrm{m}^{-2} \mathrm{~s}^{-1}$ for G-BSC, which represent the results from the $25^{\circ} \mathrm{C}$ light cycle measurement), ambient $\mathrm{CO}_{2}$ and a set of different temperatures $\left(7,12,17,25^{\circ} \mathrm{C}\right)$ for $n=6 \mathrm{C}$-BSC and $n=4 \mathrm{G}$ $\mathrm{BSC}$. The chosen temperatures are in accordance with other ecophysiological studies on BSCs (e.g., Lange et al., 1997; Lange, 1980; Weber et al., 2012; ) and represent the average temperature range of temperate Europe/Germany (see, for example, site Homburg in Raggio et al., 2017). Optimum water content was calculated as the amount of water in $\mathrm{mm}$ precipitation equivalent where NP was above $90 \%$ of maximal NP, whereas a minor depression because of suprasaturation was defined as NP being constantly below $75 \%$ of maximum NP of the sample.

To determine a possible effect of abiotic $\mathrm{CO}_{2}$ release from BSC-attached soil, the soil was measured before and after being autoclaved (see Supplement Table S6).

\subsection{Species identification}

$N$. commune and $Z$. ericetorum were studied using a light microscope (Axioskop, Zeiss, Germany) and identified using Geitler (1932) and Ettl and Gärtner (1995). Additionally, other photoautotrophic cells from one gram of soil material were identified and counted to get an overview of the photo- 
synthetic active organisms that were present in the soil after the most abundant organism of the BSC had been removed.

\subsection{Data analysis}

Light compensation points and light saturation levels of the two types of BSC were compared with a grouped $t$ test. To test for differences between mean values of cardinal points for photosynthesis (maximum NP and DR at the same temperatures, optimal water content range and water compensation points) for $\mathrm{BSC}_{\mathrm{all}}, \mathrm{BSC}_{\mathrm{soil}}$ and $\mathrm{BSC}_{\mathrm{dom}}$, a multifactorial analysis of variance (Statistica 10, Stat soft) with a Tukey post-hoc test was applied. Prior to the analysis, all data were checked for Gaussian distribution and homogeneity of variance and successfully $\log$ transformed if they did not fit these criteria. $\mathrm{BSC}_{\text {all }}, \mathrm{BSC}_{\mathrm{dom}}, \mathrm{BSC}_{\text {soil }}$ (referred to as "organization level" from here on) and temperature were always the explanatory variables, while optimum water content, water compensation point, maximum net photosynthesis and maximum dark respiration were dependent variables. Paired $t$ tests were applied to detect differences in total NP rates of $\mathrm{BSC}_{\text {all }}$ and $\mathrm{NP}$ rates of $\mathrm{BSC}_{\mathrm{dom}}$ and $\mathrm{BSC}_{\text {soil }}$ taken together. The optimum water content range was compared by statistically testing whether the upper and lower limits between the $\mathrm{BSC}_{\mathrm{dom}}, \mathrm{BSC}_{\text {soil }}$ or $\mathrm{BSC}_{\text {all }}$ differed. A multifactorial ANOVA was applied where organization level and temperature were the explanatory variables while either (a) the upper or (b) the lower limit of the optimum water content range was the dependent variable.

\section{Results}

\subsection{Gas exchange}

\subsubsection{Light-dependent photosynthetic response}

Maximum photosynthetic rates per area were reached at $2000 \mu$ mol photons $\mathrm{m}^{-2} \mathrm{~s}^{-1}$ for both C-BSC $\mathrm{Cll}_{\text {all }}$ and G-BSC $\mathrm{Bll}_{\mathrm{a}}$ (Fig. 2a and b), as it was impossible to increase PAR above this value with the GFS 3000 due to instrument limitations. Neither organism showed photoinhibition even at the highest light intensities applied $\left(2000 \mu \mathrm{mol}\right.$ photons $\left.\mathrm{m}^{-2} \mathrm{~s}^{-1}\right)$.

The light compensation point of photosynthesis was higher for G-BSC $\mathrm{all}_{\text {all }}\left(254 \pm 53 \mu \mathrm{mol}\right.$ photons $\left.\mathrm{m}^{-2} \mathrm{~s}^{-1}\right)$ compared to C-BSC all $\left(151 \pm 25 \mu \mathrm{mol}\right.$ photons $\left.\mathrm{m}^{-2} \mathrm{~s}^{-1}\right)$. However, there was no statistical support for the difference between the BSCs (grouped $t$ test: $t$ value $=2.58, \mathrm{~d} f=4$, $p=0.06$ ), mostly owing to the high SDs caused by high sample variation.

Light saturation of NP (90\% of maximal) was significantly different for both types and reached $985 \pm 31 \mu \mathrm{mol}$ photons $\mathrm{m}^{-2} \mathrm{~s}^{-1}$ for C-BSC $\mathrm{Clll}_{\text {ll }}$ and $1260 \pm 53 \mu \mathrm{mol}$ photons $\mathrm{m}^{-2} \mathrm{~s}^{-1}$ for G-BSC all (grouped $t$ test: $t$ value $=7.75, \mathrm{~d} f=4, p=0.002$ ).

\subsubsection{Net photosynthesis}

For the N. commune-dominated BSC (Fig. 3a) the organization level had a significant effect on the NP performance $(F=38.06 ; p=0.000)$. NP was up to 4.3 times higher in C$\mathrm{BSC}_{\text {dom }}$ than in C-BSC $\mathrm{Bll}_{\text {all }}$ (Tukey post-hoc test: $p=0.000$ ), whereas there was no difference between $\mathrm{C}-\mathrm{BSC}_{\mathrm{all}}$ and $\mathrm{C}$ $\mathrm{BSC}_{\text {soil. }}$. NP at $25^{\circ} \mathrm{C}$ was significantly higher than at 7 and $12^{\circ} \mathrm{C}$ for all, C-BSC $\mathrm{Bll}_{\text {all }}, \mathrm{C}-\mathrm{BSC}_{\mathrm{dom}}$ and C-BSC $\mathrm{Boil}_{\text {sil }}(F=9.41$; $p=0.000$; Tukey post-hoc test: $p 7^{\circ} \mathrm{C}=0.000 ; p 12^{\circ} \mathrm{C}=$ $0.000)$.

In the Z. ericetorum-dominated BSC (Fig. 3b) NP also changed with organization level $(F=53.61 ; p=0.000)$. There was a significant difference between G-BSC $\mathrm{B}_{\text {soil }}$ and G$\mathrm{BSC}_{\text {all }}$ (Tukey post-hoc test: $p=0.03$ ), and ${\mathrm{G}-\mathrm{BSC}_{\text {dom }} \mathrm{NP}}$ differed from both (Tukey post-hoc test: $p \mathrm{G}-\mathrm{BSC}_{\text {all }}=0.000$; $\left.p \mathrm{G}_{-} \mathrm{BSC}_{\text {soil }}=0.000\right)$. NP of G-BSC $\mathrm{Bom}_{\text {dom }} 5.5$ times higher than in $\mathrm{G}-\mathrm{BSC}_{\text {all }}$. There was no temperature dependency of $\mathrm{NP}$ visible for either the G-BSC $\mathrm{all}_{\mathrm{all}}, \mathrm{G}_{-} \mathrm{BSC}_{\mathrm{dom}}$ or G-BSC $\mathrm{B}_{\text {soil }}$.

The effects of organization level and temperature on DR can be seen in Fig. S1 and Tables S7-S9.

\subsubsection{Water dependent photosynthetic response}

The responses to changing water contents in both BSCs and their separate components are shown in two exemplifying graphs $(N$. commune in Fig. $4 \mathrm{a}$ and $Z$. ericetorum in Fig. $4 b$ ). Neither the water-response curve of $\mathrm{G}-\mathrm{BSC}_{\mathrm{dom}}$ nor C-BSC $\mathrm{B}_{\mathrm{dom}}$ resembled the response of $\mathrm{BSC}_{\mathrm{all}}$. The NP in $\mathrm{C}_{-} \mathrm{BSC}_{\mathrm{dom}}$ was 3 times higher compared to $\mathrm{C}-\mathrm{BSC}_{\text {all }}$ and doubled in $\mathrm{G}_{-} \mathrm{BSC}_{\text {dom }}$ (for statistical analyses see Tables $\mathrm{S} 1-\mathrm{S} 3$ ). Respiration in C-BSC $\mathrm{Boil}_{\text {sas }}$ watrikingly small in a $N$. commune-dominated system and did not resemble the respiratory response in $\mathrm{C}-\mathrm{BSC}_{\text {all }}$ or the $\mathrm{C}-\mathrm{BSC}_{\mathrm{dom}}$, whereas respiration was pronounced in a $Z$. ericetorum-dominated $\mathrm{G}$ $\mathrm{BSC}_{\mathrm{all}}$. Respirations of G-BSC $\mathrm{Boil}_{\text {sil }}, \mathrm{G}-\mathrm{BSC}_{\text {all }}$ and G-BSC $\mathrm{C}_{\mathrm{dom}}$ all seemed to follow the same pattern, although the values differed slightly between all three, with highest rates

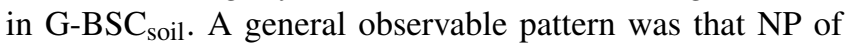
$\mathrm{BSC}_{\text {soil }}$ and $\mathrm{BSC}_{\mathrm{dom}}$ combined never equalled NP of $\mathrm{BSC}_{\text {all }}$ in both BSC types (paired $t$ test; results for $N$. commune crust: $t$ value $=-6.43, \mathrm{~d} f=23, p=0.000 ; Z$. ericetorum crust: $t$ value $=-5.05, \mathrm{~d} f=15, p=0.000)$.

C-BSC $\mathrm{Bom}_{\mathrm{dom}}$ showed a minor depression in net photosynthesis at high water contents (Table 1). An even smaller depression was visible in the $\mathrm{C}_{-} \mathrm{BSC}_{\text {all }}$. Due to the cross sensitivity of the GFS 3000 analyzer for $\mathrm{CO}_{2}$ and $\mathrm{H}_{2} \mathrm{O}$ molecules, it was impossible to measure such high water contents for the C$\mathrm{BSC}_{\mathrm{dom}}$, as the amount of water brought into the measuring system was too high to produce reliable measurement values. Also in $\mathrm{G}_{-} \mathrm{BSC}_{\text {dom }}$ and in $\mathrm{G}_{-} \mathrm{BSC}_{\text {all }}$ a reduction of $\mathrm{NP}_{\max }$ by $25 \%$ occurred only after $63-71 \%$ normalized water content.

The optimum water content had a smaller range for $\mathrm{C}$ $\mathrm{BSC}_{\text {all }}(1.21$ to $1.39 \mathrm{~mm})$ compared to $\mathrm{C}-\mathrm{BSC}_{\mathrm{dom}}(0.56$ to

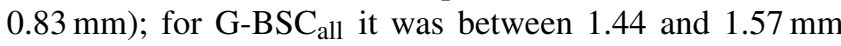



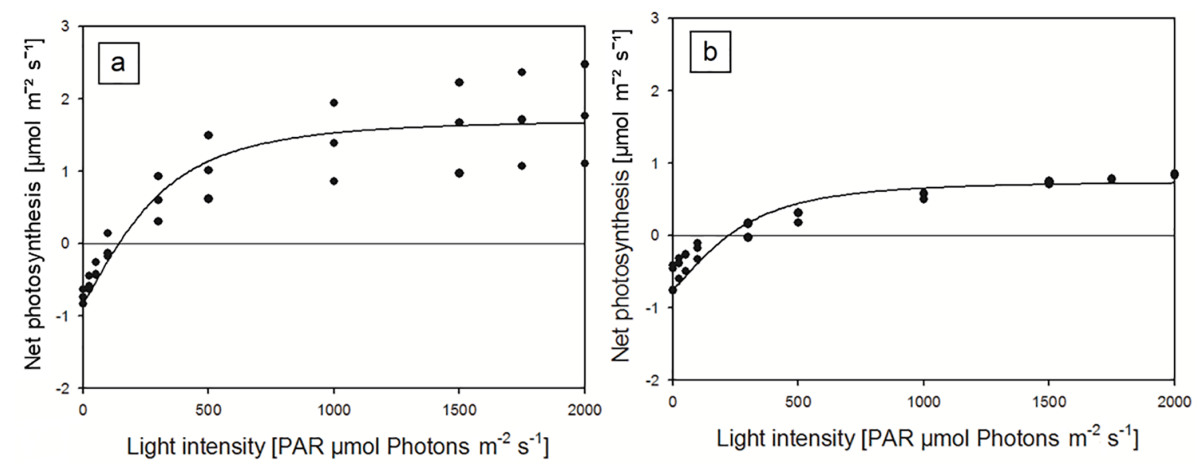

Figure 2. Light-dependent photosynthetic response curves of intact $\mathrm{BSC}$ with (a) $\mathrm{C}-\mathrm{BSC}_{\mathrm{all}}$ and (b) $\mathrm{G}-\mathrm{BSC}_{\mathrm{all}} ; n=3$; $\mathrm{PAR}=\mathrm{photosynthetic}$ active radiation.

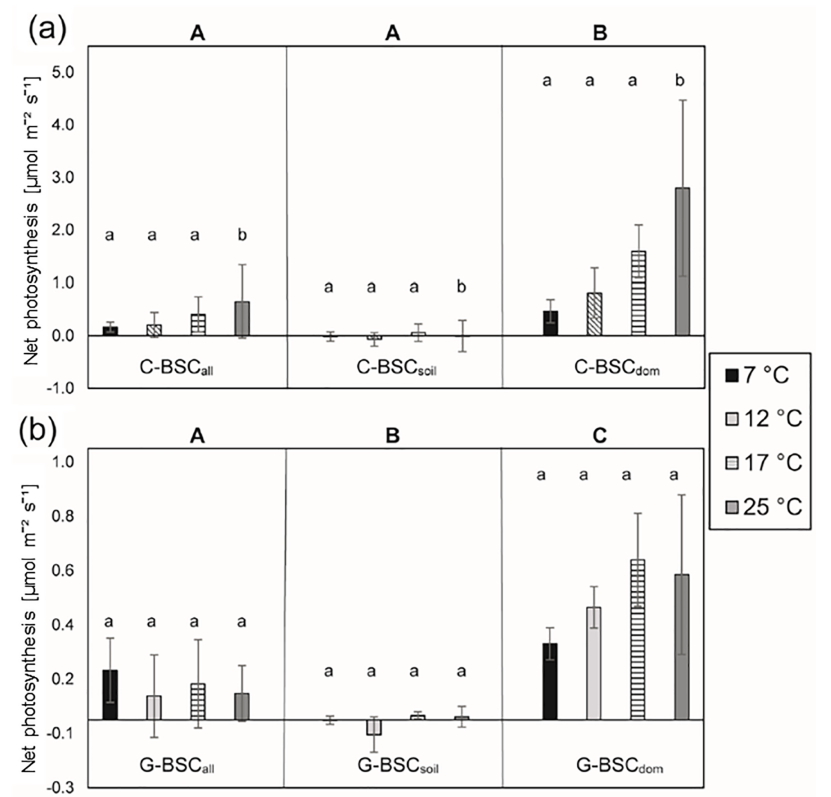

Figure 3. Temperature dependent net photosynthesis per area in (a) N. commune- and (b) Z. ericetorum-dominated BSCs, separated dominant organism and separate soil. Capital letters indicate significant differences in organization level between BSC, organism and soil; lower case letters compare temperature differences of one of the organization groups only. Sample size was $n=6$ for $N$. commune and $n=4$ for $Z$. ericetorum.

and for $\mathrm{G}_{-} \mathrm{BSC}_{\mathrm{dom}}$ between 0.58 and $0.79 \mathrm{~mm}$. The values for optimum water content between both $\mathrm{BSC}_{\text {all }}$ types were close, as well as between both $\mathrm{BSC}_{\text {dom }}$ types which show similar values, independent of species. The maximum water holding capacity was $3.29 \pm 0.89 \mathrm{~mm}$ for $\mathrm{C}-\mathrm{BSC}_{\mathrm{all}}$ and $4.66 \pm 1.38 \mathrm{~mm}$ for $\mathrm{G}_{-} \mathrm{BSC}_{\text {all }}$. In percent dry weight $\mathrm{C}$ $\mathrm{BSC}_{\text {dom }}$ could hold up to $4562 \%$, while sustaining $88 \%$ of its maximum $\mathrm{NP}$ rate, but $\mathrm{G}-\mathrm{BSC}_{\mathrm{dom}}$ could only take up $435 \%$ with $18 \%$ of its maximum NP rate (see Fig. 4).

Both $\mathrm{BSC}_{\mathrm{all}}$ optimum water content ranges were significantly higher than the corresponding $\mathrm{BSC}_{\mathrm{dom}}$ optimum water
Table 1. Water content at which net photosynthesis is below $75 \%$ of maximum net photosynthesis including SDs.

\begin{tabular}{ll}
\hline \multicolumn{2}{c}{ Normalized water content [\%] } \\
\hline C-BSC $_{\text {all }}^{\mathrm{a}}$ & $84.3 \pm 15.9$ \\
C-BSC $_{\text {dom }}^{\mathrm{a} b}$ & $71.7 \pm 16.5$ \\
G-BSC $_{\text {all }}^{\mathrm{b}}$ & $70.9 \pm 15.1$ \\
G-BSC $_{\text {dom }}^{\mathrm{b}}$ & $62.8 \pm 18.5$ \\
\hline
\end{tabular}

Superscripted letters represent statistical differences.

content ranges (multifactorial ANOVA $N$. commune: $\mathrm{d} f=$ $2, F=15.24, p=0.000$; multifactorial ANOVA $Z$. ericetorum: $\mathrm{d} f=2, F=30.08, p=0.000)$. The optimal water content differed heavily with organization level and was broadest in $\mathrm{BSC}_{\mathrm{dom}}$ for both BSC types (Fig. 5; N. commune: $F=43.20, p=0.000 ; Z$. ericetorum: $F=66.28, p=$ 0.000). This pattern is expected, as extracellular polymeric substances have a different water holding capacity than soil. Nonetheless, both $\mathrm{BSC}_{\mathrm{all}}$ and their respective $\mathrm{BSC}_{\mathrm{dom}}$ samples showed a broad optimum water content range (Fig. 5), compared to soil alone. Both limits of $\mathrm{BSC}_{\mathrm{dom}}$ in both types were not statistically different, which was also the case for $\mathrm{BSC}_{\mathrm{all}}$ (for statistical results see Tables S4 and S5).

\subsection{Net photosynthesis per area vs. net photosynthesis per chlorophyll content}

A significant difference between NP calculated per area and NP per chlorophyll content became obvious after comparing the results: NP/chlorophyll was up to 2 orders of magnitude higher in C-BSC than in G-BSC, although G-BSC had an up to 181 times higher chlorophyll content per area (Table S9), which would theoretically enable the G-BSC to assimilate more $\mathrm{CO}_{2}$ than the $\mathrm{C}$-BSC. To investigate whether the higher NP rate in C-BSC was due to actual ecophysiological differences (such as a carbon concentrating mechanism, CCM) or because of the reference value used, we calculated the effect 

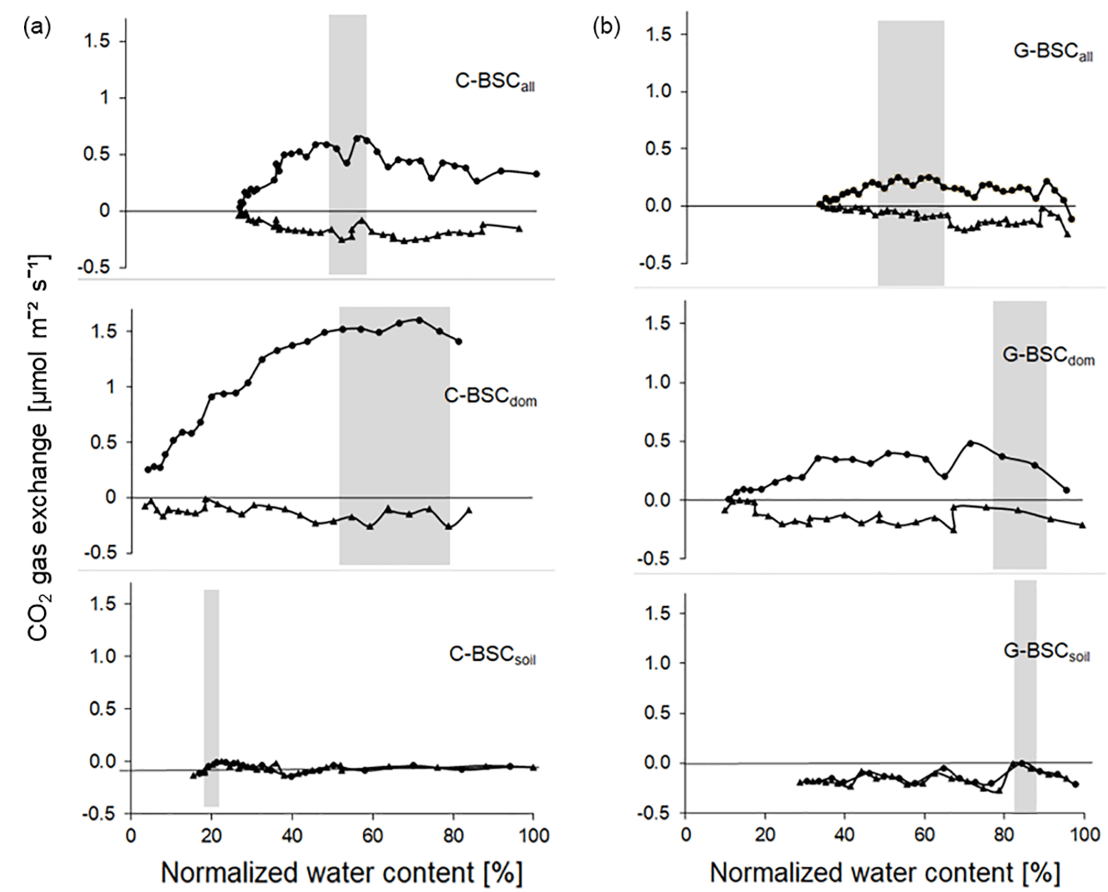

Figure 4. Responses of net photosynthesis (dots) and dark respiration (triangles) to normalized water content for intact BSC, the isolated dominant organisms and in soil at $12{ }^{\circ} \mathrm{C}$. Measurements were taken at saturating light and a temperature of $12{ }^{\circ} \mathrm{C}$. (a) C-BSC (985 $\mu$ mol photons $\left.\mathrm{m}^{-2} \mathrm{~s}^{-1}\right)$ and (b) G-BSC $\left(1260 \mu \mathrm{mol}\right.$ photons $\left.\mathrm{m}^{-2} \mathrm{~s}^{-1}\right)$. Grey bars indicate optimum water content.

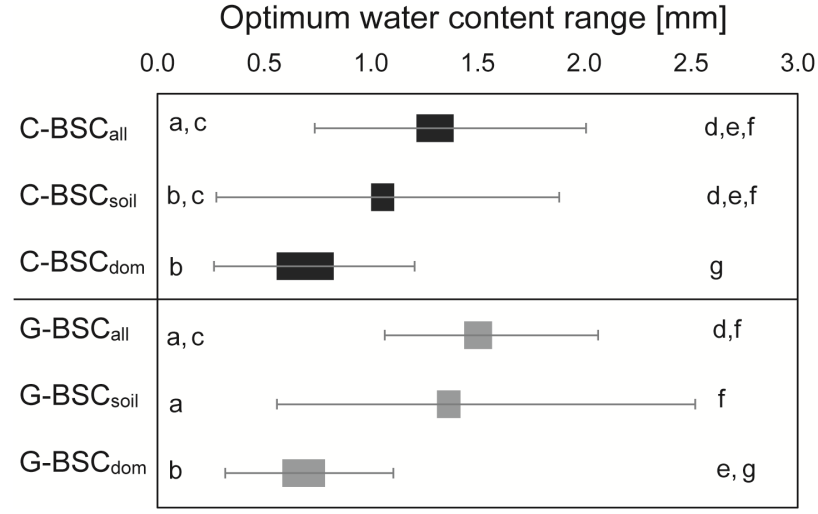

Figure 5. Optimum water content range, in $\mathrm{mm}$ precipitation, of a cyanobacteria-dominated BSC (upper three, black bars) and a green-algae-dominated BSC (lower three, grey bars) and their respective separated components. Sample size is $n=24$ for all C-BSC and 16 for all G-BSC. Letters represent statistical differences of the upper and lower limits, respectively ( $a, b, c=$ lower limit; d, e, f, $\mathrm{g}=$ upper limits).

the reference value had on the NP rates between both investigated organisms.

First, NP per area was calculated for C-BSC $\mathrm{C}_{\mathrm{dom}}$ and $\mathrm{G}-$ $\mathrm{BSC}_{\mathrm{dom}}$ at each temperature. Then the ratio of C-BSC $\mathrm{Bom}_{\mathrm{dom}}$ to $\mathrm{G}-\mathrm{BSC}_{\mathrm{dom}}$ was calculated for NP/area rates. The same ratio of NP/area rates was calculated between $\mathrm{C}-\mathrm{BSC}_{\text {all }}$ and $\mathrm{G}$ $\mathrm{BSC}_{\text {all }}$.

Afterwards, NP was calculated on a chlorophyll basis for the same samples and each temperature. The ratio of $\mathrm{NP} /$ chlorophyll between C-BSC $\mathrm{dom}_{\text {and }}$ G-BSC $\mathrm{Bdom}_{\mathrm{d}}$ and then between $\mathrm{C}-\mathrm{BSC}_{\mathrm{all}}$ and $\mathrm{G}-\mathrm{BSC}_{\mathrm{all}}$ was calculated. If both ratios, NP/area and NP/chlorophyll, were of equal size, it would be possible to conclude that only ecophysiological reasons, such as a CCM, were responsible for the much higher NP rates in the cyanobacteria-dominated crust. However, the NP/chlorophyll ratio was always higher than the $\mathrm{NP} /$ area ratio (grouped $t$ test: $t$ value $=-2.167, \mathrm{~d} f=14$, $p=0.05$; Fig. 6), e.g., $\mathrm{BSC}_{\text {all }}$ at $25^{\circ} \mathrm{C}$ : NP/area 6 times higher in $\mathrm{C}_{-} \mathrm{BSC}_{\text {all }}$; $\mathrm{NP} /$ chlorophyll 42 times higher in $\mathrm{C}$ $\mathrm{BSC}_{\text {all }}$.

\subsection{Photosynthetic active and heterotrophic organisms in soil}

The number of cells of photosynthetic active organisms in soil samples was similar for both study sites $(26 \pm 3$ cells per gram of soil for $\mathrm{MH}$ and $19 \pm 2$ for PL). The abiotic gas release, measured after autoclaving the soil, was about $20 \%$ of the gas exchange before autoclaving (Table S6). 


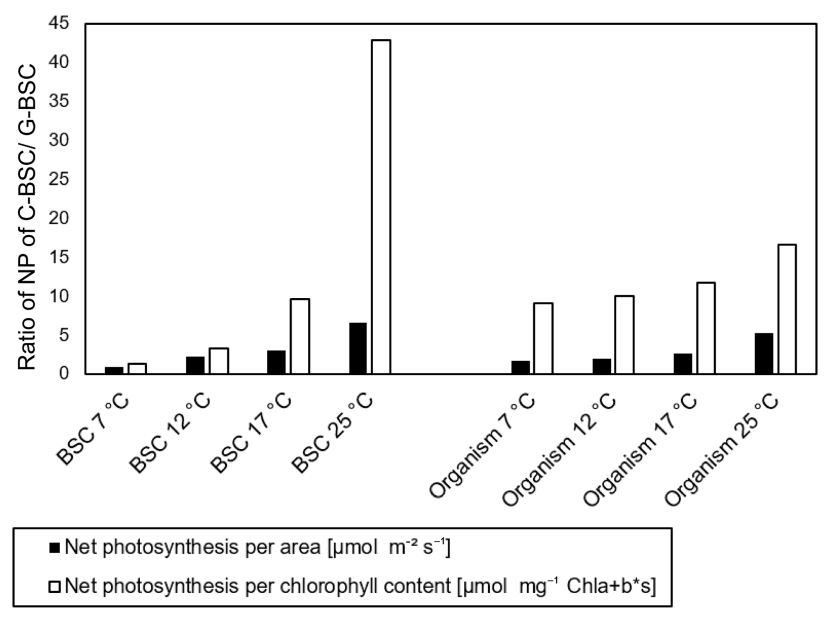

Figure 6. Difference in the ratio of net photosynthesis based on either area or chlorophyll content between $\mathrm{C}-\mathrm{BSC}_{\mathrm{dom}}$ and $\mathrm{G}-\mathrm{BSC}_{\mathrm{dom}}$

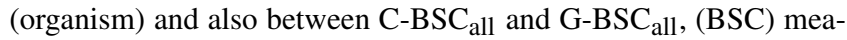
sured at different temperatures. $\mathrm{NP}=$ net photosynthesis.

\section{Discussion}

In this study, we received profound evidence that early successional BSCs expose a considerable physiological flexibility which in turn might be responsible for their pronounced stress tolerance and their success in heavily disturbed habitats. As light is one of the major drivers for photosynthetic rates in BSCs, the cardinal points in response to light were examined. For BSC photosynthetic organisms the light level compensating respiration normally lies between 60 and 100 photons $\mathrm{m}^{-2} \mathrm{~s}^{-1}$ (Green and Proctor, 2016), which indicates comparability to classical "sun plant" features. Our results support these findings, and the variation within our measurements, indicated by high SDs, reflects a very high sampling site internal variation. This may be a result of spatially small-scale shading of, e.g., Calluna vulgaris in the Mehlinger heathland or higher plants at the border of a parking lot. As high-light-adapted organisms, light saturation points of BSC organisms are almost always at, or above, $700 \mu \mathrm{mol}$ photons $\mathrm{m}^{-2} \mathrm{~s}^{-1}$ (Green and Proctor, 2016). This is well supported by our data with a light saturation point (LSP) consistently being over $900 \mu \mathrm{mol}$ photons $\mathrm{m}^{-2} \mathrm{~s}^{-1}$ for both C-BSC $\mathrm{Call}_{\text {and }}$ G-BSC $\mathrm{Bll}_{\text {all }}$.

The second major driver for photosynthetic responses in BSCs is water; thus, the photosynthetic cardinal points in response to water content were examined. The lack of differences in the optimal water content between C-BSC $\mathrm{C}_{\mathrm{dom}}$ and G-BSC $\mathrm{dom}_{\mathrm{dom}}$, and between the G-BSC $\mathrm{C}_{\mathrm{all}}$ and C-BSC $\mathrm{C}_{\mathrm{all}}$, indicates that both organism groups share the same functional role in the BSC consortium and can operate at nearoptimal conditions over a variety of different water contents, as it would be expected for highly stress-tolerant crust pioneer species. Explaining the variability in ecophysiological response to water content are the relatively high SDs and broad range of optimal water contents for the dominant organisms, compared to other species (e.g., $0.25-0.35 \mathrm{~mm}$ in Fulgensia fulgens, Lange et al., 1998). Optimal water content of a BSC in a temperate habitat (Homburg; $3.32 \mathrm{~mm}$; Europe, Germany; Colesie et al., 2014) is $2 \mathrm{~mm}$ higher than in our study $(1.21-1.57 \mathrm{~mm})$, probably due to the low biomass in the investigated early successional habitats in this study. Colesie et al. (2014) proposed that biomass is the driving factor shaping the optimal water content within a system, with low biomass needing less water to achieve maximum net photosynthesis. A general difference between $\mathrm{BSC}_{\text {all }}$ and $\mathrm{BSC}_{\text {dom }}$ concerning optimal water content is likely due to the different water holding capacities of the soil. Even at high

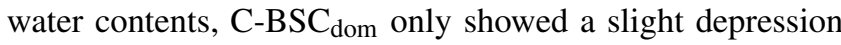
of NP (Fig. 4). Depression in G-BSC dom $_{\text {occurred relatively }}$ late (Table 1). Considering that these crusts live in a temperate climate, where precipitation is high enough to support forest vegetation, a depression of NP at high water contents might be a disadvantage, although a depression is common in other BSC organisms (e.g., several lichens; Lange et al., 1997). Additionally, $N$. commune can gain up to 20-30 times its dry weight in water (Satho et al., 2002; Shaw et al., 2003), which is stored mostly in exopolymeric substances (EPS) (Tomaselli and Giovannetti, 1993; Kovacik, 2000). Z. ericetorum only shows a slight difference in morphology when dried (Fritsch, 1916; Holzinger et al., 2010) and therefore cannot store as much water as $N$. commune. In addition, $Z$. ericetorum is rarely exposed to high water contents around the cell and therefore may show an earlier depression of net photosynthesis at high water contents. Furthermore, a carbon concentrating mechanism was detected in N. commune (see Fig. S2), but not in Z. ericetorum. Through this mechanism, the internal $\mathrm{CO}_{2}$ partial pressure around the carboxylating enzymes is increased, which improves photosynthetic efficiency. Simultaneously, $\mathrm{CCMs}$ decrease the $\mathrm{CO}_{2}$ concentration around the photosynthesizing cells. Through this increasing diffusion gradient for $\mathrm{CO}_{2}$ transports the adverse effects of suprasaturation with water can be overcome (Lange, 2001).

The third major driver of photosynthesis in BSCs is temperature. Temperature showed different effects on net photosynthesis rates in both organism groups. In C-BSC $\mathrm{C}_{\text {all }} \mathrm{NP}$ was only higher at 17 and $25^{\circ} \mathrm{C}$ compared to lower temperatures $\left(7\right.$ and $\left.12^{\circ} \mathrm{C}\right)$, whereas in G-BSC $\mathrm{Bll}_{\text {all }}$ no difference was observable at any temperature. This indicates a high temperature tolerance, which was also noticed by Borstoff et al. (2005), who could not pinpoint an exact temperature optimum for a BSC during field studies in the western Mojave Desert. BSC components are not necessarily adapted to high temperatures. Although soil surfaces at which BSCs live can reach up to $50^{\circ} \mathrm{C}$ on a normal summer day (Hoppert et al., 2004), the organisms are already dry and inactive when these temperatures are reached (Raggio et al., 2017).

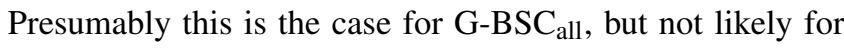
the $\mathrm{C}-\mathrm{BSC}_{\mathrm{all}}$ in this study. Due to the high water holding ca- 
pacities of Nostoc thalli, activity periods during daytime are prolonged. This may coincide with a temperature increase, as has been reported for gelatinous, slow drying lichens (e.g., Collema tenax; Lange, 2001). In Antarctica, where Novis et al. (2007) conducted a study on the importance of $\mathrm{N}$. commune in Antarctic habitats, it was observed that this organism tends to have its highest NP rates at unusually high temperatures $\left(20.5^{\circ} \mathrm{C}\right)$. However, the results of Novis et al. (2007) should be treated with caution, because it is very likely that organisms corresponding to the description of $N$. commune from polar and temperate regions may be genetically distinct (Novis and Smissen, 2006) and therefore should not be compared so readily. Nevertheless, in general cyanobacteria are better adapted to high temperatures than green algae (Castenholz and Waterbury, 1989; Lange et al., 1998).

In summary, both crust types were largely unaffected by changes in water content and had high light compensation and exceptionally high light saturation points. Net photosynthesis of $\mathrm{G}_{-} \mathrm{BSC}_{\mathrm{all}}$ was unaffected by increasing temperatures, while $\mathrm{C}_{-} \mathrm{BSC}_{\text {all }}$ only had increased NP rates with higher temperatures. Both fit well within known ecophysiological patterns of different BSC components (see Lange and Belnap, 2001) and show a lower net photosynthesis compared to BSC components of advanced successional stages (see, for example, Lange, 2001). The high physiological variability in photosynthetic cardinal points places $N$. commune and Z. ericetorum crusts as similar to other BSC contributors, such as lichens and bryophytes. This characterizes these organisms as stress tolerators within the typical patterns of Grime's CSR model (Grime and Pierce, 2012). Life history traits of stress tolerators include slow growth rates, high rates of nutrient retention, low phenotypic plasticity and a response to environmental stresses through physiological variability (Grime and Pierce, 2012).

To aid in future investigations on BSCs, methodological procedures will now be discussed. First, an unavoidable complication in gas exchange measurements of BSCs is to take abiotic release of $\mathrm{CO}_{2}$ into account (Inglima et al., 2009; Weber et al., 2012), aside from the biotic respiration of BSC, phototrophic and heterotrophic organisms. The $\mathrm{CO}_{2}$ release of alkaline and saline substrates can even exceed those of organic activity (Shanhun et al., 2012; Sancho et al., 2016). The abiotic release in this study accounted for only 20 and $26 \%$ (MH and PL, respectively) of total soil respiration rate, which is close to what Weber et al. (2012) measured in the Succulent Karoo and Shanhun (2013) with 25\% in Antarctica.

Secondly, besides an obvious effect of organization level on NP and DR rates (see Fig. 3, and Fig. S1), the waterresponse curves of $\mathrm{BSC}_{\mathrm{all}}$ and $\mathrm{BSC}_{\mathrm{dom}}$ alone differed. Although the courses of their curves were similar, net photosynthesis rates were never equally high for $\mathrm{BSC}_{\mathrm{all}}$ and $\mathrm{BSC}_{\mathrm{dom}}$ (Fig. 4a and b). Adding NP rates of $\mathrm{BSC}_{\text {soil }}$ to $\mathrm{BSC}_{\text {dom }}$ did not equal the values and $\mathrm{NP}$ was always higher in $\mathrm{BSC}_{\mathrm{dom}}$ compared to $\mathrm{BSC}_{\text {all }}$ in both crust types. This fact confirms the view of BSCs being communities or systems rather than random accumulations of organisms and strengthens the need for long-term field monitoring studies of an intact BSC. Causes that might have led to the unexpected NP rate could be self-shading or water logging. An organism lying on top of an intact BSC has a species-specific structure (e.g., lobes of $N$. commune over one another or the spherical structure of $Z$. ericetorum algal mats) that will be changed and rearranged while being washed and placed separately in a cuvette. Through this thallus manipulation and subsequent exposure, the internal diffusion resistance is decreased and the self-shading protective mechanisms in those organisms damaged. Aeroterrestrial filamentous green algae, such as Klebsormidium crenulatum, form multilayer mat-like structures on top of or interwoven with the upper millimeters of soil (Karsten, and Rindi, 2010), contributing to self-shading of individual filaments inside a population. The same is visible in $Z$. ericetorum. While rearranging the organisms the protective layer of dead or highly melanized cells on top of the crust is either removed or shifted, resulting in unprotected but highly active cells being subjected to high light intensities. So, although the high light intensities will cause damage, through reactive oxygen species production for example, the NP response itself is higher than before. Overlapping lobes in $N$. commune may also cause reduced NP rates in an intact BSC system. Bowker et al. (2002) hypothesized that sunscreen pigments produced by Nostoc protect other, less pigmented taxa, which includes a self-shading protective mechanism for lower lobes of the same species. Recent data suggest that shading effects due to such three dimensional spatial arrangements may be more important than previously assumed (Karsten and Rindi, 2010). Another possibility that could lead to decreased NP in a complete BSC system is water logging between filaments of the organisms (Garcia-Pichel and Belnap, 2001). The diffusion resistance of $\mathrm{CO}_{2}$ in water is higher than in air (Cowan et al., 1992) and will reduce NP rates. A water suprasaturated system, as it can be found in the closely growing mats of $Z$. ericetorum or $N$. commune, could have a disadvantage against a widely spread organism surface in the cuvette, that is aerated all around.

Thirdly, we propose a methodological consideration concerning reference values of photosynthesis in gas exchange measurements in general. To compare cardinal points of photosynthesis between organisms or samples of the same species it is necessary to base the photosynthetic values on either dry weight, area or chlorophyll content, which are the most common reference values in literature. In Fig. 6 it becomes apparent that the ratios of NP per area and NP per chlorophyll content in C-BSC $\mathrm{Bdom}_{\mathrm{d}}$ and $\mathrm{G}-\mathrm{BSC}_{\mathrm{dom}}$ differ substantially, although the ratio should be similar if both reference values were equally suited for gas exchange measurements in those organisms. This difference is most probably due to the different composition of photoactive pigments in the two organism groups. Terrestrial green algae pos- 
sess chlorophyll $a$ and $b$, whereas cyanobacteria only possess chlorophyll $a$, which is considered in the calculation of chlorophyll content. But cyanobacteria also possess phycobilisomes and super antennae allowing capture of photosynthetically active radiation from low photon flux densities and the green part of the spectrum (Lüttge, 2011), which are not considered in calculations of this reference value. A much more suitable value than chlorophyll content is therefore area, which has been used in this study. Nonetheless, this value is not perfect as there are probably many dead cells still bound to the EPS of living cells that distort area measurements, and of course it is not useful if fruticose lichens are investigated. Additionally, the arrangement of the BSC does have an influence on the photosynthetic signal, considering that $N$. commune is almost flat while $Z$. ericetorum has a more spherical structure as the BSC gets older. It is therefore of immense importance to decide which reference value should be used when comparing the ecophysiological response of BSC systems.

\section{Conclusions}

In this study, we present the first detailed ecophysiological dataset describing photosynthetic performance of early successional BSCs. A relative temperature independence of NP as well as late or no water depression and an adaptation to high light intensities was demonstrated for both early successional BSCs and their separated dominant organisms. This broad physiological amplitude indicates strong stress tolerance in both organism groups and may be the reason for their success in heavily disturbed areas. The results can be incorporated into global-scale carbon cycle models. Additionally, this study emphasizes the importance of measuring a complete BSC rather than their single components, as not only taxonomic composition but also spatial arrangement seems to be an important factor shaping photosynthetic response in BSC systems. Lastly, the methodological approach demonstrated that a comparison of photosynthetic values in cyanobacteria and green algae should be based on area rather than chlorophyll content.

Data availability. The data can be publicly accessed as an excel file at ResearchGate (https://doi.org/10.13140/RG.2.2.14763.13605; Szyja et al., 2017).

\section{The Supplement related to this article is available online at https://doi.org/10.5194/bg-15-1919-2018-supplement.}

Competing interests. The authors declare that they have no conflict of interest.
Special issue statement. This article is part of the special issue " $\mathrm{Bi}$ ological soil crusts and their role in biogeochemical processes and cycling". It is a result of the BIOCRUST3 conference, Moab, USA, 26 to 30 September 2016.

Acknowledgements. We would like to thank Andreas Klein and the Untere Naturschutzbehörde of Kaiserslautern for providing us access to the Mehlinger heath. We would also like to thank Vincent Felde and his students at the Justus Liebig University of Gießen for providing us information about soil data of the both investigated systems. Additionally, we would like to thank Emilio Rodriguez-Caballero for the opportunity to be part of this special issue on biological soil crusts. Finally, we want to thank the three referees for their expert opinions on this paper, which helped to improve it.

Edited by: Emilio Rodriguez-Caballero

Reviewed by: Thomas Fischer and two anonymous referees

\section{References}

Bailey, D., Mazurak, A. P., and Rosowski, J. R.: Aggregation of soil particles by algae, J. Phycol., 9, 99-101, 1973.

Belnap, J.: The potential roles of biological soil crusts in dryland hydrologic cycles, Hydrol. Process., 20, 3159-3178, 2006.

Belnap, J. and Eldridge, D.: Disturbance and recovery of biological soil crusts, in: Biological soil crusts: structure, function, and management, Springer, Berlin, Heidelberg, 363-383, 2001.

Belnap, J., Büdel, B., and Lange, O. L.: Biological soil crusts: characteristics and distribution, in: Biological soil crusts: structure, function, and management, Springer, Berlin, Heidelberg, 3-30, 2001.

Belnap, J., Weber, B., and Büdel, B.: Biological Soil Crusts as an Organizing Principle in Drylands, in: Biological soil crusts: An Organizing Principle in Drylands, Ecological Studies 226, edited by: Weber, B., Büdel, B., and Belnap, J., Springer International Publishing Switzerland, Cham, Switzerland, 3-13, 2016.

Bowker, M. A., Reed, S. C., Belnap, J., and Phillips, S. L.: Temporal variation in community composition, pigmentation, and Fv/Fm of desert cyanobacterial soil crusts, Microb. Ecol., 43, 13-25, 2002.

Bowker, M. A., Maestre, F. T., and Escolar, C.: Biological crusts as a model system for examining the biodiversity - ecosystem function relationship in soils, Soil Biol. Biochem., 42, 405-417, 2010.

Brostoff, W. N., Sharifi, M. R., and Rundel, P. W.: Photosynthesis of cryptobiotic soil crusts in a seasonally inundated system of pans and dunes in the western Mojave Desert, CA: Field studies, Flora-Morphology, Distribution, Functional Ecololgy Of Plants, 200, 592-600, 2005.

Büdel, B.: Ecology and diversity of rock-inhabiting cyanobacteria in tropical regions, Eur. J. Phycol., 34, 361-370, 1999.

Büdel, B.: Biological soil crusts in European temperate and Mediterranean regions, in: Biological soil crusts: Structure, function, and management, Springer, Berlin, Heidelberg, 75-86, 2001. 
Büdel, B.: Eukaryotic algae, in: Plant desiccation tolerance, Springer, Berlin, Heidelberg, 45-63, 2011.

Büdel, B., Dulić, T., Darienko, T., Rybalka, N., and Friedl, T.: Cyanobacteria and Algae of Biological Soil Crusts, in: Biological soil crusts: An Organizing Principle in Drylands, Ecological Studies 226, edited by: Weber, B., Büdel, B., and Belnap, J., Springer International Publishing Switzerland, Cham, Switzerland, 55-80, 2016.

Castenholz, R. W. and Waterbury, J. B.: Oxygenic photosynthetic bacteria, Group I. Cyanobacteria. Bergey's manual of systematic bacteriology, 3, International Publishing Switzerland, Cham, Switzerland, 1710-1789, 1989.

Colesie, C., Green, T. G. A., Haferkamp, I., and Büdel, B.: Habitat stress initiates changes in composition, $\mathrm{CO}_{2}$ gas exchange and C-allocation as life traits in biological soil crusts, ISME J., 8, 2104-2115, 2014.

Colesie, C., Felde, V. J. M. N. L., and Büdel, B.: Composition and Macrostructure of Biological Soil Crusts, in: Biological soil crusts: An Organizing Principle in Drylands, Ecological Studies 226, edited by: Weber, B., Büdel, B., and Belnap, J., Springer International Publishing Switzerland, Cham, Switzerland, 159172, 2016

Cowan, I. R., Lange, O. L., and Green, T. G. A.: Carbon-dioxide exchange in lichens: determination of transport and carboxylation characteristics, Planta, 187, 282-294, 1992.

Dojani, S., Büdel, B., Deutschewitz, K., and Weber, B.: Rapid succession of biological soil crusts after experimental disturbance in the Succulent Karoo, South Africa, Appl. Soil Ecol., 48, 263269, 2011.

Elbert, W., Weber, B., Burrows, S., Steinkamp, J., Büdel, B., Andreae, M. O., and Pöschl, U.: Contribution of cryptogamic covers to the global cycles of carbon and nitrogen, Nat. Geosci., 5, 459-462, 2012.

Escolar, C., Martínez, I., Bowker, M. A., and Maestre, F. T.: Warming reduces the growth and diversity of biological soil crusts in a semi-arid environment: implications for ecosystem structure and functioning, Philos. T. Roy. Soc. B, 367, 3087-3099, 2012.

Ettl, H. and Gärtner, G.: Syllabus der Boden-, Luft- und Flechtenalgen, Fischer, Stuttgart, Jena, New York, 1995.

Fischer, T., Veste, M., Schaaf, W., Dümig, A., Kögel-Knabner, I., Wiehe, W., Bens, O., and Hüttl, R. F.: Initial pedogenesis in a topsoil crust 3 years after construction of an artificial catchment in Brandenburg, NE Germany, Biogeochemistry, 101, 165-176, 2010.

Fritsch, F. E.: The morphology and ecology of an extreme terrestrial form of Zygnema (Zygogonium) ericetorum (Kuetz.), Hansg, Ann. Bot.-London, 1, 135-149, 1916.

Garcia-Pichel, F. and Belnap, J.: Small-scale environments and distribution of biological soil crusts, in: Biological soil crusts: Structure, function, and management, Springer, Berlin, Heidelberg, 193-201, 2001.

Gaylarde, C. C. and Morton, L. G.: Deteriogenic biofilms on buildings and their control: a review, Biofouling, 14, 59-74, 1999.

Geitler, L.: Dr. L. Rabenhorst's Krypotgamen-Flora von Deutschland, Österreich und der Schweiz, in: 14. Band: Die Algen, Cyanophyceae, Akademische Verlagsgesellschaft, Leipzig, 1932.

Green, A. T. G. and Proctor, M. C. F.: Physiology of Photosynthetic Organisms Within Biological Soil Crusts: Their Adapta- tion, Flexibility, and Plasticity, in: Biological Soil Crusts: An Organizing Principle in Drylands, Springer International Publishing, Cham, Switzerland, 347-381, 2016.

Grime, J. P. and Pierce, S.: The evolutionary strategies that shape ecosystems, John Wiley \& Sons, Chichester, UK, 2012.

Hawes, I., Howard-Williams, C., and Vincent, W. F.: Desiccation and recovery of Antarctic cyanobacterial mats, Polar. Biol., 12, 587-594, 1992.

Holzinger, A., Tschaikner, A., and Remias, D.: Cytoarchitecture of the desiccation-tolerant green alga Zygogonium ericetorum, Protoplasma, 243, 15-24, 2010.

Hoppert, M., Reimer, R., Kemmling, A., Schröder, A., Günzl, B., and Heinken, T.: Structure and reactivity of a biological soil crust from a xeric sandy soil in Central Europe, Geomicrobiol. J., 21, 183-191, 2004.

Housman, D. C., Powers, H. H., Collins, A. D., and Belnap, J.: Carbon and nitrogen fixation differ between successional stages of biological soil crusts in the Colorado Plateau and Chihuahuan Desert, J. Arid Environ., 66, 620-634, 2006.

Hu, C., Liu, Y., Song, L., and Zhang, D.: Effect of desert soil algae on the stabilization of fine sands, J. Appl. Phycol., 14, 281-292, 2002.

Inglima, I., Alberti, G., Bertolini, T., Vaccari, F. P., Gioli, B., Miglietta, F., Cotrufo, M. F., and Peressotti, A.: Precipitation pulses enhance respiration of Mediterranean ecosystems: the balance between organic and inorganic components of increased soil $\mathrm{CO}_{2}$ efflux, Glob. Change Biol., 15, 1289-1301, 2009.

Karsten, U. and Rindi, F.: Ecophysiological performance of an urban strain of the aeroterrestrial green alga Klebsormidium sp. (Klebsormidiales, Klebsormidiophyceae). Eur J Phycol, 45, 426435, 2010.

Karsten, U., Lütz, C., and Holzinger, A.: Ecophysiological performance of the aeroterrestrial green alga Klebsormidium crenulatum (charophyceae, streptophyta) isolated from an alpine soil crust with an emphasis on desiccation stress, J. Phycol., 46, 1187-1197, 2010.

Kovacik, L.: Cyanobacteria and algae as agents of biodeterioration of stone substrata of historical buildings and other cultural monuments, in: Proceedings of the New Millennium International Forum on Conservation of Cultural Property, Kongju National University, Kongju, 5-8 December 2005, 44-58, 2000.

Kuske, C. R., Yeager, C. M., Johnson, S., Ticknor, L. O., and Belnap, J.: Response and resilience of soil biocrust bacterial communities to chronic physical disturbance in arid shrublands, ISME J., 6, 886-897, 2012.

Landesamt für Geologie und Bergbau Rheinland-Pfalz: Die Geologische Übersichtskarte von Rheinland-Pfalz im Maßstab $1: 300000, \quad$ http://www.geoportal.rlp.de/portal/karten.html? LAYER[zoom]=1\&LAYER[id]=24212\&LAYER[visible] $=0 \&$ LAYER[querylayer] $=0$, last access: 5 September 2016 .

Lange, O. L.: Moisture content and $\mathrm{CO}_{2}$ exchange of lichens, Oecologia, 1, 82-87, 1980.

Lange, O. L.: Photosynthesis of soil-crust biota as dependent on environmental factors, in: Biological soil crusts: structure, function, and management, Springer, Berlin, Heidelberg, 217-240, 2001.

Lange, O. L. and Belnap, J.: How Biological Soil Crusts Became Recognized as a Functional Unit: A Selective History, in: Biological soil crusts: An Organizing Principle in Drylands, Ecological Studies 226, edited by: Weber, B., Büdel, B., and Belnap, J., 
Springer International Publishing Switzerland, Cham, Switzerland, 15-33, 2016.

Lange, O. L., Kidron, G. J., Budel, B., Meyer, A., Kilian, E., and Abeliovich, A.: Taxonomic composition and photosynthetic characteristics of the biological soil crusts' covering sand dunes in the western Negev Desert, Funct. Ecol., 6, 519-527, 1992.

Lange, O. L., Belnap, J., Reichenberger, H., and Meyer, A.: Photosynthesis of green algal soil crust lichens from arid lands in southern Utah, USA: role of water content on light and temperature responses of $\mathrm{CO}_{2}$ exchange, Flora, 192, 1-15, 1997.

Lange, O. L., Belnap, J., and Reichenberger, H.: Photosynthesis of the cyanobacterial soil-crust lichen Collema tenax from arid lands in southern Utah, USA: Role of water content on light and temperature responses of $\mathrm{CO}_{2}$ exchange, Funct. Ecol., 12, 195202, 1998

Lüttge, U.: Cyanobacteria: multiple stresses, desiccation-tolerant photosynthesis and di-nitrogen fixation, in: Plant Desiccation Tolerance, Springer, Berlin, Heidelberg, 23-43, 2011.

Maestre, F. T., Bowker, M. A., Cantón, Y., Castillo-Monroy, A. P., Cortina, J., Escolar, C., Escudero, A., Lázaro, R., and Martínez, I.: Ecology and functional roles of biological soil crusts in semi-arid ecosystems of Spain, J. Arid Environ., 75, 1282-1291, 2011.

Makhalanyane, T. P., Valverde, A., Velázquez, D., Gunnigle, E., Van Goethem, M. W., Quesada, A., and Cowan, D. A.: Ecology and biogeochemistry of cyanobacteria in soils, permafrost, aquatic and cryptic polar habitats, Biodivers. Conserv., 24, 819840,2015

Novis, P. M. and Smissen, R. D.: Two genetic and ecological groups of Nostoc commune in Victoria Land, Antarctica, revealed by AFLP analysis, Antarct. Sci., 18, 573-581, 2006.

Novis, P. M., Whitehead, D., Gregorich, E. G., Hunt, J. E., Sparrow, A. D., Hopkins, D. W., Elberling, B., and Greenfield, L. G.: Annual carbon fixation in terrestrial populations of Nostoc commune (Cyanobacteria) from an Antarctic dry valley is driven by temperature regime, Glob. Change Biol., 13, 1224-1237, 2007.

Pandey, K. D., Shukla, P. N., Giri, D. D., and Kashyap, A. K.Cyanobacteria in alkaline soil and the effect of cyanobacteria inoculation with pyrite amendments on their reclamation, Biol. Fert. Soils, 41, 451-457, 2005.

Pluis, J. L. A.: Algal crust formation in the inland dune area, Laarder Wasmeer, the Netherlands, Vegetatio, 113, 41-51, 1994.

Porada, P., Weber, B., Elbert, W., Pöschl, U., and Kleidon, A.: Estimating global carbon uptake by lichens and bryophytes with a process-based model, Biogeosciences, 10, 6989-7033, https://doi.org/10.5194/bg-10-6989-2013, 2013.

Porada, P., Weber, B., Elbert, W., Pöschl, U., and Kleidon, A.: Estimating impacts of lichens and bryophytes on global biogeochemical cycles, Global Biogeochem. Cy., 28, 71-85, 2014.

Raggio, J., Green, T. G. A., Sancho, L. G., Pintado, A., Colesie, C., Weber, B., and Büdel, B.: Metabolic activity duration can be predicted from macroclimatic data for biological soil crust habitats across Europe, Geoderma, 306, 10-17, 2017.

Raven, J.: Carbon, in: Ecology of Cyanobacteria II, Springer Netherlands, Houten, the Netherlands, 443-460, 2012.

Reed, S. C., Koe, K., Sparks, J. P., Housman, D., Zelikova, T. J., and Belnap, J.: Changes to dryland rainfall result in rapid moss mortality and altered soil fertility, Nat. Clim. Change, 2, 752$755,2012$.
Reisser, W.: The hidden life of algae underground, in: Algae and Cyanobacteria in Extreme Environments, Springer Netherlands, Houten, the Netherlands, 47-58, 2007.

Rindi, F.: Diversity, distribution and ecology of green algae and cyanobacteria in urban habitats, in: Algae and cyanobacteria in extreme environments, Springer, Houten, the Netherlands, 619638, 2007.

Ronen, R. and Galun, M.: Pigment extraction from lichens with dimethyl sulfoxide (DMSO) and estimation of chlorophyll degradation, Environ. Exp. Bot., 24, 239-245, 1984.

Ruby, A.: Neukirchen, Mehlingen, Baalborn, Geschichten der Dörfer auf dem Kreis, Verlag Franz Arbogast, Otterbach, 1979.

Sancho, L. G., Belnap, J., Colesie, C., Raggio, J., and Weber, B.: Carbon budgets of biological soil crusts at micro-, meso-, and global scales, in: Biological Soil Crusts: An Organizing Principle in Drylands, Springer International Publishing, Cham, Switzerland, 287-304, 2016.

Satoh, K., Hirai, M., Nishio, J., Yamaji, T., Kashino, Y., and Koike, H.: Recovery of photosynthetic systems during rewetting is quite rapid in a terrestrial cyanobacterium, Nostoc commune, Plant Cell Physiol., 43, 170-176, 2002.

Seckbach, J.: Algae and cyanobacteria in extreme environments, Vol. 11, Springer Science and Business Media, Luxemburg, Berlin, 2007.

Shanhun, F.: Partitioning biotic and abiotic components of soil $\mathrm{CO}_{2}$ fluxes using subsurface $\mathrm{CO}_{2}$ dynamics and stable carbon isotopes, Taylor Valley, Antarctica, Doctoral dissertation, Lincoln University, Lincoln, New Zealand, 2013.

Shanhun, F. L., Almond, P. C., Clough, T. J., and Smith, C. M.: Abiotic processes dominate $\mathrm{CO}_{2}$ fluxes in Antarctic soils, Soil Biol. Biochem., 53, 99-111, 2012.

Shaw, E., Hill, D. R., Brittain, N., Wright, D. J., Täuber, U., Marand, H., Helm, R. F., and Potts, M.: Unusual water flux in the extracellular polysaccharide of the cyanobacterium Nostoc commune, Appl. Environ. Microb., 69, 5679-5684, 2003.

Solomon, S., Qin, D., Manning, R. B. et al.: Technical Summary, in: Climate Change 2007 The Physical Science Basis. Contribution of Working Group I to the Fourth Assesment Report of the Intergovernmental Panel in Climate Change, edited by: Solomon, S., Qin, D., Manning, M., Chen, Z., Marquis, M., Averyt, K. B., Tignor, M., and Miller, H. L., Cambridge University Press, Cambridge and New York, 2007.

Stanula, A. S.: Einfluss von verschiedenen landwirtschaftspflegerischen Maßnsahmen auf biologische Bodenkrusten in der Mehlinger Heide, Diploma thesis, TU Kaiserslautern, Kaiserslautern, Germany, 2011.

Szyja, M., Büdel, B., and Colesie, C.: Eco-physiological characterization of early successional biological soil crusts in heavily human impacted areas - Implications for conservation and succession, Biogeosciences Discuss., https://doi.org/10.5194/bg-2017-369, in review, 2017 (data available at: https://doi.org/10.13140/RG.2.2.14763.13605, last access: 24 March 2018).

Tamaru, Y., Takani, Y., Yoshida, T., and Sakamoto, T.: Crucial role of extracellular polysaccharides in desiccation and freezing tolerance in the terrestrial cyanobacterium Nostoc commune, Appl. Enivron. Microb., 71, 7327-7333, 2005.

Tomaselli, L. and Giovannetti, L.: Survival of diazotrophic cyanobacteria in soil, World J. Microb. Biot., 9, 113-116, 1993. 
Tomaselli, L., Lamenti, G., Bosco, M., and Tiano, P.: Biodiversity of photosynthetic micro-organisms dwelling on stone monuments, Int. Biodeter. Biodegr., 46, 251-258, 2000.

Veste, M., Breckle, S. W., Eggert, K., and Littmann, T.: Vegetation pattern in arid sand dunes controlled by biological soil crusts along a climatic gradient in the Northern Negev desert, Basic Appl. Dryland Res., 5, 1-17, 2011.

Walker, L. R. and Willig, M. R.: An introduction to Terrestrial Disturbances, in: Ecosystems of Disturbed Ground. Ecosystems of the World 16, edited by: Walker, L. R., Elsevier, Amsterdam, 1999.

Weather station of the Agrarmeteorology RheinlandPalatinate: Morlautern: http://www.am.rlp.de/Internet/AM/ NotesAM.nsf/amweb/ebaffa60a3dac562c1257171002e8a44? OpenDocument\&TableRow $=2.6 \# 2$, last access: 5 September 2016.

Webb, R. H. and Wilshire, H. G.: Environmental effects of off-road vehicles: impacts and management in arid regions, Springer Science and Business Media, New York, USA, 2012.
Webb, R. H., Wilshire, H. G., and Henry, M. A.: Natural recovery of soils and vegetation following human disturbance, in: Environmental effects of Off-road vehicles, Springer, New York, NY, USA, 279-302, 1983.

Weber, B., Graf, T., and Bass, M.: Ecophysiological analysis of moss-dominated biological soil crusts and their separate components from the Succulent Karoo, South Africa, Planta, 236, 129-139, 2012.

Zedda, L., Gröngröft, A., Schultz, M., Petersen, A., Mills, A., and Rambold, G.: Distribution patterns of soil lichens across the principal biomes of southern Africa, J. Arid Environ., 75, 215-220, 2011.

Zelikova, T. J., Housman, D. C., Grote, E. E., Neher, D. A., and Belnap, J.: Warming and increased precipitation frequency on the Colorado Plateau: implications for biological soil crusts and soil processes, Plant Soil, 355, 265-282, 2012. 